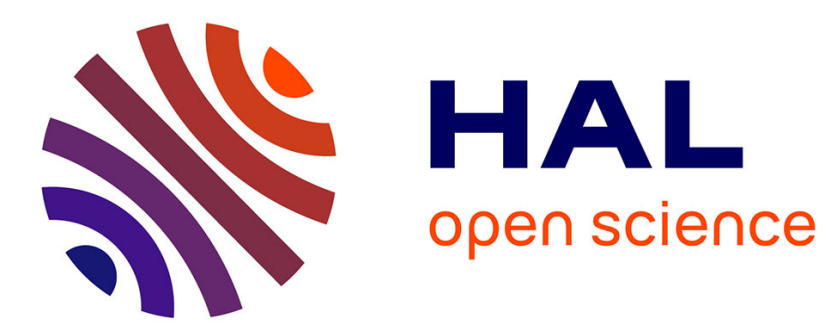

\title{
LARGE DIFFUSION OXYGEN SENSOR IN MICROELECTRONIC TECHNOLOGY
}

\author{
M. Gogé, D. Bauza, G. Velasco
}

\section{To cite this version:}

M. Gogé, D. Bauza, G. Velasco. LARGE DIFFUSION OXYGEN SENSOR IN MICROELECTRONIC TECHNOLOGY. Journal de Physique Colloques, 1986, 47 (C1), pp.C1-795-C1-799. 10.1051/jphyscol:19861121 . jpa-00225518

\section{HAL Id: jpa-00225518 https://hal.science/jpa-00225518}

Submitted on 1 Jan 1986

HAL is a multi-disciplinary open access archive for the deposit and dissemination of scientific research documents, whether they are published or not. The documents may come from teaching and research institutions in France or abroad, or from public or private research centers.
L'archive ouverte pluridisciplinaire HAL, est destinée au dépôt et à la diffusion de documents scientifiques de niveau recherche, publiés ou non, émanant des établissements d'enseignement et de recherche français ou étrangers, des laboratoires publics ou privés. 


\title{
LARGE DIFFUSION OXYGEN SENSOR IN MICROELECTRONIC TECHNOLOGY
}

\author{
M. GOGÉ⿱ ${ }^{*}$ D. BAUZA ${ }^{+*}$ and G. VELASCO* \\ +Laboratoire de Thermodynamique et d'Electrochimie des oxydes. \\ Université Paris XII, Avenue C. de Gaulie, F-94010 Créteil Cedex, \\ France \\ *Laboratoire Central de Recherche Thomson-CSF, Domaine de \\ Corbevilie, F-91401 orsay, France
}

\begin{abstract}
Résumé - En utilisant les méthodes typiques de la microélectronique, le L.C.R. a conçu des microjauges auxquelles le changement d'échelle confère de nombreux avantages. Nous présentons les principaux résultats obtenus sur ces capteurs, en vue de leur utilisation en régulateurs de combustion.
\end{abstract}

\begin{abstract}
Using typical technics of the microelectronics, the L.C.R. realizes microgauges, for which the scale-change presents many advantages. We show the main results obtained on these sensors before an use as compustion regulators.
\end{abstract}

\section{I - INTRODUCTION}

Applying on new materials the technological methods that made it possible to develop the microelectronics may lead to the creation of a new group of components, possessing the well known advantages of the microelectronic components such as the reliability, the reproducibility, the low production costs and the possibility of integrating their functions $/ 1 \%$.

An example of this approach is the realization of an oxygen sensor which is no longer three-dimensional but plane. It is prepared by means of thick and thin films technology, and it has all the required functions for the analysis of a test dose and for titrating gaseous components $/ 1,2,3 /$.

II - DESCRIPTION OF THE MICROSENSOR

This microsensor comprises a potentiometric gauge based on stabilized zirconia, whose principle is well-known. It allows a potential drop of about 1 volt as the gas mixture to be analyzed is passing from an oxidizing to a reducing composition. This part is equivalent to the sensor "lambda" already realized in serial production to regulate mixtures of air/combustible to the stoichiometric ratio. A porous platinum electrode acts as a catalyst and brings the gas mixture to thermodynamic equilibrium. This electrode is open to the atmosphere through an electrochemical pump of porous stabilized zirconia (fig.1). When one forces a current to pass through the electrochemical pump the test gas composition is changed and consequently the reaction threshold of the potentiometric gauge is displaced. These gauges seem to be particularly well fit to control gas burners and our study has been carried out under conditions similar to those in an operating gas burner.

The failures of the sensors, except those due to bad connections between two different phases, may be caused by permanent physical or chemical constraints 
(chemical reactions, interdiffusion dependent upon temperature and environment) or thermal constraints brought on by repeatedly lighting and extinguishing the burner. Our experiments give information about the first parameters.

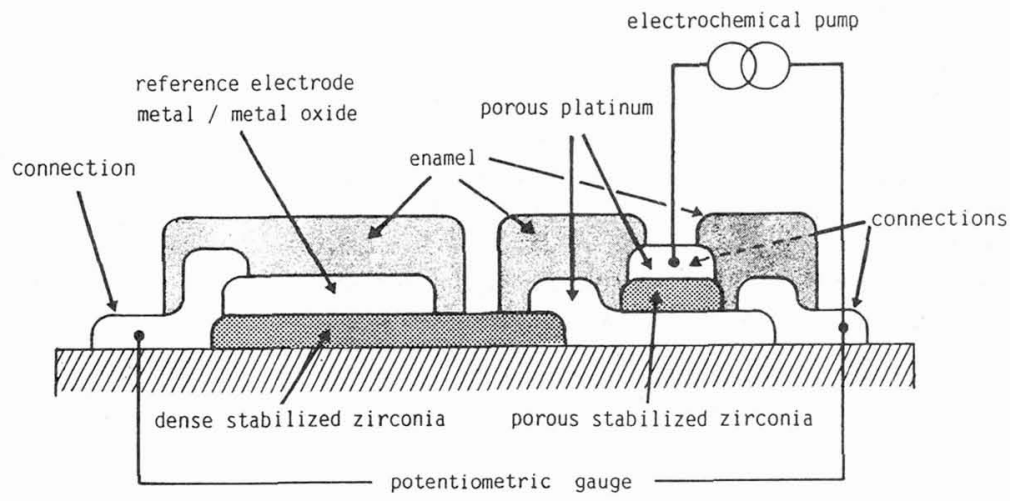

Fig. 1 : cross-section of a microionic sersor

III - RESULTS

DISPLACEMENT OF THE RESPONSE BY PUMP CURRENT

The figure 2 shows the response of the gauge with different current magnitudes running in the electrochemical pump. Inverting the current direction allows the analysis of gas compositions with excess combustible with regard to the stoechiometric composition.

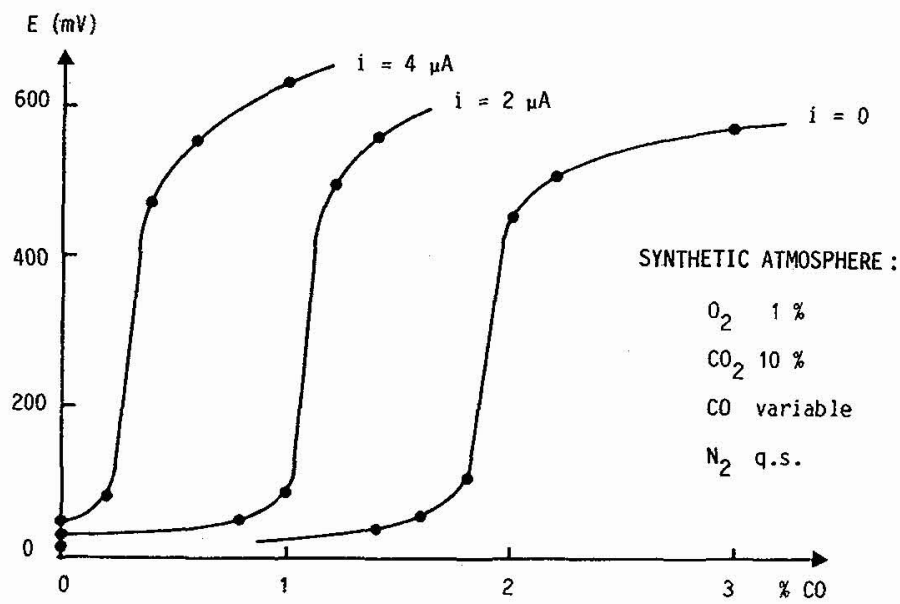

Fig. 2 : Responses of sensohs far several pumping currents

THE TEMPERATURE INFLUENCE ON THE POTENTIAL DROP

The application considered here does not make use of the response according to Nernst's equation, but of the e.m.f. shift of the potentiometric part of the gauge around the stoichiometric point. This means that a precise temperature regulation is not necessary. The curves of the figure 3 show the response of a microgauge in an atmosphere of combusted natural gas without pumping current. The response of a 
conventional massive gauge is also presented for comparison. Microionic and massive gauges have not similar e.m.f.. It is due for a great part to the references: in one case, air is the gas reference and in the other case the chemical potential of the oxygen reference is imposed by the equilibrium $\mathrm{Pd} / \mathrm{PdO}$ and slightly varies with the temperature; the substrate and the enamel can also have an influence on the e.m.f. of the microionic gauge by shortcircuiting the potentiometric part of the electrolyte. However, the temperature has little influence on the potential drop, and the signal is usable between 650 and $800 \mathrm{C}$.

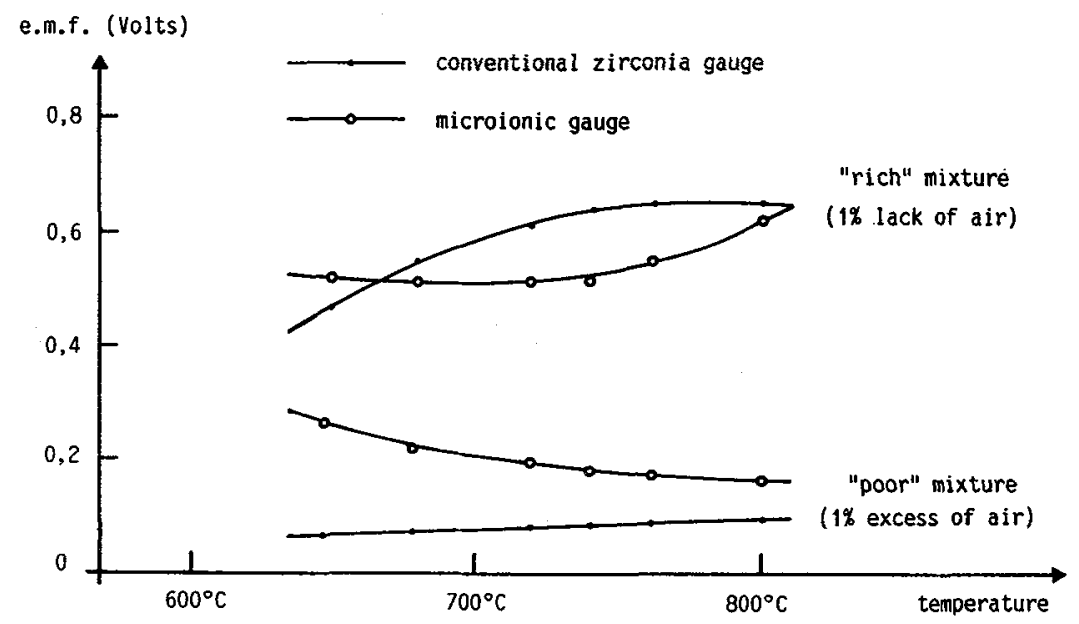

Fig. 3 : Staechiometric response versus temperature

e.m.f. (Volts)

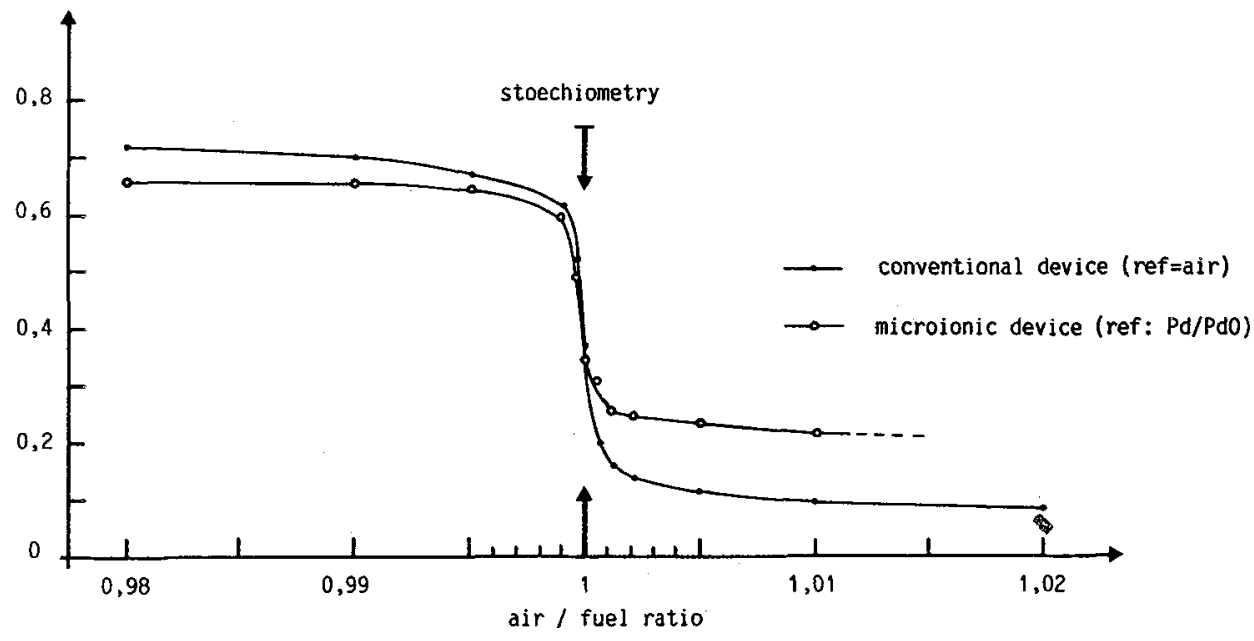

Fig. 4 : Response near stoechiometry after 1200 hrs ageing 
RESPONSE AT THE POINT OF STOICHIOMETRY AFTER AGEING

The figure 4 shows the response of a micro-ionic gauge around the stoichiometric point, after $1200 \mathrm{hrs}$ of operation at $752 \mathrm{C}$. The response of a massive gauge situated on the same place, having air as reference, is showed for comparison.

\section{AGEING TEST OF THE GAUGES}

The ageing of the gauges has been studied at constant temperature $(740 \mathrm{C})$. They have been operating in oxidizing atmosphere, representative of that in a boiler (operating with excess air). Note that this atmosphere is the least favourable for this type of gauges, with an internal reference electrode consisting of a mixture of a metal and its oxide. Once every two weeks the operation was stopped and deteriorated gauges were removed and examined.

In some gauges the connections between the different phases had been broken because of the repeated heating and cooling, or upon dismantling. This represents $40 \%$ of the failures (example: sensor $29-7$ after 44 days of operation).

After normal operation for more than one month an ageing could be seen on several gauges, for example sensors 29-6 (after 38 days) and 29-7 (after 34 days): There was a simultaneous drift of the e.m.f. in oxidizing and reducing atmospheres. Characteristic for these gauges were leaks in the enamel covering the reference electrode. ( $60 \%$ of the failures).

Finally, after 1500 hours one third of the gauges still operated normally. The original potential drop of $0.8 \mathrm{~V}$ had decreased slightly, but in no case below $0.6 \mathrm{~V}$.

On figure 5 are shown some characteristic examples of these evolutions as a function of time.
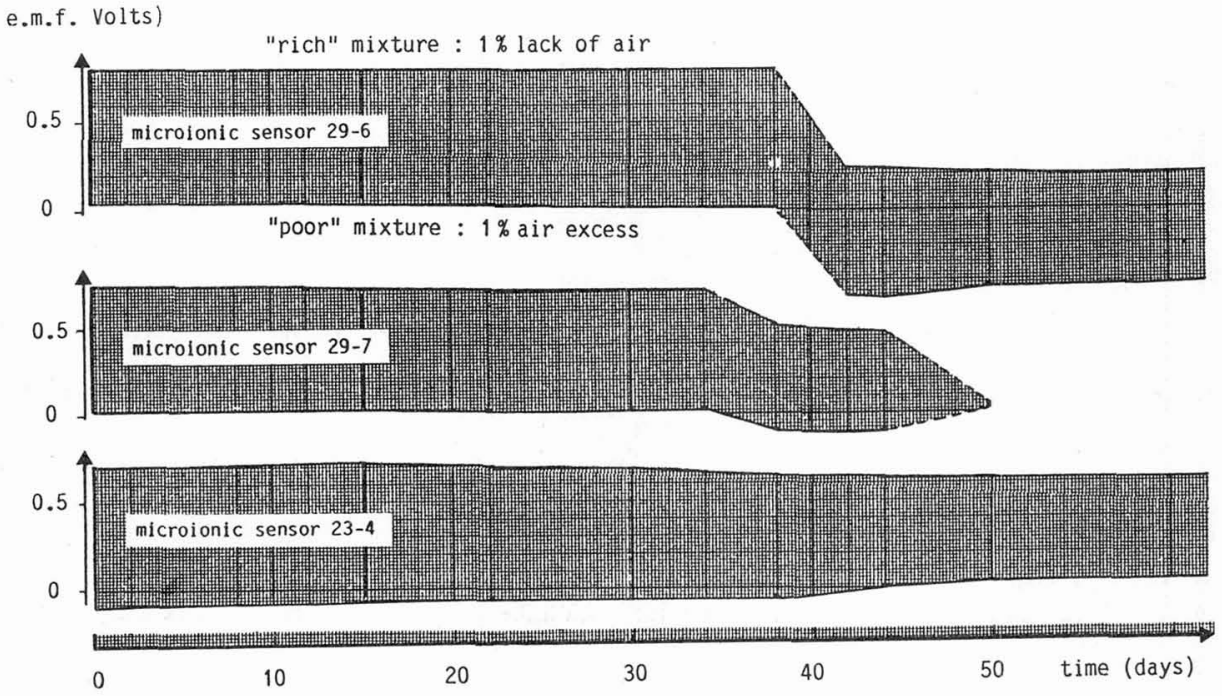

Fig. 5 : Response of several microionic sensors during ageing 


\section{IV - CONCLUSION}

The gauges realized by the micro-ionic technology show a suitable behaviour in combusted natural gas atmosphere for more than two months. In particular the duration of the internal reference electrode is acceptable, given that the cracks in the enamel or its physical and electrochemical porosity do not expose the reference electrode to the ambient atmosphere.

The failures are for their majority due to the cracking of the enamel layer and then to its oxygen permeability.

The response of the micro-ionic gauges has been compared to that of the conventional ceramic gauges. The differences between the measured e.m.f. can easily be explained by the structure of the micro-ionic sensor. The life-time of such gauges exceed 1500 hours, which is acceptable for numerous applications.

\section{$V$ - REFERENCES}

/1/ Velasco, G., Solid State Ionics 9-10 (1983) 783

/2/ Velasco, G., Schnell, J.P., Phys. E : Sci.Instr. 16 (1983) 973

/3/ Velasco, G., Schnell, J.P., Crozet, M., Sensors and actuators 2 (1983) 371 